\title{
Parental coping mechanisms in children with congenital heart disease at tertiary cardiac centre
}

\author{
Subina Bajracharya ${ }^{1}$, Ajit Shrestha ${ }^{2}$ \\ ${ }^{1}$ Assistant Professor, Chitwan Medical College, College of Nursing, Nepal, ${ }^{2}$ Associate Professor, Chitwan Medical \\ College Teaching Hospital, Chitwan, Nepal
}

Background: Congenital Heart Diseases (CHD) are among the most pervasive and serious chronic illnesses. Parents of children with a chronic condition must cope with greater demands and adopt different behaviors in order to lessen the impact on the family structure. Aims and Objectives: This study aims to explore the coping mechanism used by parents of children with CHD. Materials and Methods: This descriptive study included 100 parents of children with $\mathrm{CHD}$ selected through non-probability purposive sampling technique. Data were collected by interview and analyzed using descriptive statistics. Result: This study revealed that parents of preschool children used more coping mechanism (mean score 30.53 out of total score 57), followed by parents of adolescence (mean score 30). Parents of first-born children with CHD used less coping mechanism (mean score 28.08). Parents of female children used more coping mechanism (mean score 29.52), fathers of children with CHD used more coping mechanism (mean score 29.78), and parents of operated children used more coping mechanism (mean score 29.11). Conclusion: Parental coping mechanism was found to be affected by age, sex, operative status and birth order of children and also by the sex of parent. These findings strongly indicate the need for proper counseling service to parents so that healthy coping is reinforced.

Key words: Parental coping, Coping mechanism, Congenital heart disease

\section{INTRODUCTION}

Coronary heart disease affects 8 of every 1,000 neonates and accounts for two-thirds of all major birth defects along with neural tube defect. ${ }^{1}$ It is an important cause for morbidity and mortality in pediatric age group. These chronic health problems not only impact the well-being of the patient, but also pose a risk for parents of such children by causing ongoing stress and undermining stability of the family and their ability to cope.

Factors contributing to parental distress are variable, but do not appear to be related to the severity of the malformation suffered by their child. ${ }^{2}$ In children who are diagnosed in the perinatal period and early infancy, the parents tend to suffer more stress during the progression of pregnancy and early infancy due to the diagnosis of chronic illness which may threat the well-being of the child. Care giving demands are very high, especially in the early stages of illness. ${ }^{3}$

In response of stress, psychological balance is maintained by adjustive patterns of behavior which is termed as coping. Such stress is dealt by various conscious and unconscious strategies called coping abilities. Coping doesn't imply mastery over the crisis; rather it is the process to solve the situation. $^{4}$

Despite the fact that CHD is the second most prevalent chronic illness in childhood little research has examined the family impact of CHD. ${ }^{5}$ Many of the existing studies of family stress and coping hold that the effects of life events and strains contribute to psychological distress. Research on parental coping in children with CHD is limited implying an emergent need to conduct study on this topic. 


\section{MATERIALS AND METHODS}

A descriptive research design was adopted to explore the coping mechanism used by parents of children with CHD attending Shahid Gangalal National Heart Centre (SGNHC), Bansbari. Coping checklist (CCL) Asian version developed by Rao, Subbakrishna and Prabhu (1989) was adopted to assess The coping mechanism of parents were assessed by Nepali version of Coping checklist that was developed after 2 stage back translation of Coping checklist (CCL) Asian version, developed by Rao, Subbakrishna and Prabhu (1989). ${ }^{6}$

The original CCL comprised of 70 items, including 6 aspects of coping viz. problem focused; seeking social support; passive acceptance; avoidance; religious and emotion focused. After revision and pretesting the checklist constituted of 57 items.

Hundred parents attending inpatient and outpatient department of SGNHC were selected using non-probability purposive sampling technique. Data were collected from $22^{\text {nd }}$ August 2010 to $17^{\text {th }}$ September 2010 after ethical approval from the research committee of Nursing Campus, Maharajgunj. Data collection was done by interview method using semi-structured questionnaire for socio demographic data and coping mechanism after obtaining verbal consent from all the respondents. After collection data were coded, edited and analyzed using descriptive statistics. Statistical package for the social sciences (SPSS) for windows was used for the analysis of data.

\section{RESULTS}

Parental coping mechanism was studied by interviewing 100 parents of children with CHD attending SGNHC. Sixty mothers and 40 fathers were involved in the study with age range of 17 to 58 years. The demographic characters of the responders are shown in Table 1.

The characteristics of the 100 children with CHD and their demographic data are shown on Table 2.

The parent's coping mechanisms were recorded and scored according to coping checklist. The scores were then analyzed in relation to the age of the child in Table 3, in relation to the birth order of the child in Table 4 , in relation to the sex of the child in Table 5 , in relation to the sex of the parent in Table 6 and in relation to the surgical intervention to the child in Table 7.

\section{DISCUSSION}

The demographic data of 100 parents of children with CHD showed that most of them (48\%) were from the age group 20-30 years. Among them 30\% were Brahmin, 87\% were Hindu, 39\% were educated up to secondary level, $20 \%$ were illiterate, 34\% were involved in household work, 33\% in agriculture, $54 \%$ had joint family, and were from urban area of living, $64 \%$ of the parents had used their personal savings for the treatment of the child, while $9 \%$ had taken loan, and 5\% had sold property.

\begin{tabular}{|c|c|c|c|}
\hline Variables & Percent & Variables & Percent \\
\hline Age group (in years) & & Sex & \\
\hline Less than 20 & 8.0 & Mother & 60.0 \\
\hline $20-30$ & 48.0 & Father & 40.0 \\
\hline $31-40$ & 33.0 & & \\
\hline $41-50$ & 8.0 & & \\
\hline $51-60$ & 3.0 & & \\
\hline Ethnicity & & Occupation & \\
\hline Brahmin & 30.0 & Agriculture & 33.0 \\
\hline Chhetri & 21.0 & Business & 11.0 \\
\hline Newar & 3.0 & Service & 15.0 \\
\hline Gurung & 4.0 & Household work & 34.0 \\
\hline Magar & 7.0 & Others & 7.0 \\
\hline Tamang/sherpa & 7.0 & & \\
\hline Others & 28.0 & & \\
\hline Religion & & Education level & \\
\hline Hindu & 87.0 & Illiterate & 20.0 \\
\hline Buddhist & 9.0 & Primary level & 22.0 \\
\hline Muslim & 1.0 & Secondary level & 39.0 \\
\hline Christian & 3.0 & $\begin{array}{l}\text { Higher secondary } \\
\text { or above }\end{array}$ & 19.0 \\
\hline Type of family & & Area of living & \\
\hline Nuclear & 46.0 & Rural & 46.0 \\
\hline Joint & 54.0 & Urban & 54.0 \\
\hline
\end{tabular}

\begin{tabular}{|c|c|c|c|}
\hline Variables & Percent & Variables & Percent \\
\hline Age group of child & & $\begin{array}{l}\text { Source of the expense } \\
\text { for treatment }\end{array}$ & \\
\hline $\begin{array}{l}\text { Neonate } \\
\text { (birth-1 month) }\end{array}$ & 1.0 & Personal saving & 64.0 \\
\hline $\begin{array}{l}\text { Infant } \\
\text { (1-12 months) }\end{array}$ & 24.0 & $\begin{array}{l}\text { Personal saving } \\
\text { and loan }\end{array}$ & 22.0 \\
\hline Toddler (1-3 year) & 22.0 & Loan & 9.0 \\
\hline $\begin{array}{l}\text { Preschooler } \\
\text { (3-6 years) }\end{array}$ & 19.0 & Selling of property & 5.0 \\
\hline $\begin{array}{l}\text { School age } \\
(6-12 \text { years })\end{array}$ & 21.0 & & \\
\hline $\begin{array}{l}\text { Adolescence } \\
\text { (12-14 years) }\end{array}$ & 13.0 & & \\
\hline $\begin{array}{l}\text { Family history of } \\
\text { congenital anomaly }\end{array}$ & & Sex of the child & \\
\hline Present & 8.0 & Male & 56.0 \\
\hline Absent & 92.0 & Female & 44.0 \\
\hline Surgery & & Birth order & \\
\hline Done & 19.0 & First born & 50.0 \\
\hline Not done & 81.0 & Consecutive born & 50.0 \\
\hline
\end{tabular}

Asian Journal of Medical Sciences | Jul-Aug 2016 | Vol 7 | Issue 4 


\begin{tabular}{|c|c|c|c|c|c|c|c|}
\hline \multirow{2}{*}{$\begin{array}{l}\text { Age of the } \\
\text { child }\end{array}$} & \multicolumn{6}{|c|}{ Coping mechanism } & \multirow{2}{*}{$\begin{array}{l}\text { Total } \\
\text { score }\end{array}$} \\
\hline & $\begin{array}{l}\text { Problem } \\
\text { focused }\end{array}$ & $\begin{array}{l}\text { Seeking social } \\
\text { support }\end{array}$ & $\begin{array}{c}\text { Passive } \\
\text { acceptance }\end{array}$ & Avoidance & Religious & $\begin{array}{l}\text { Emotion } \\
\text { focused }\end{array}$ & \\
\hline \multicolumn{8}{|c|}{ Birth-1 month } \\
\hline Mean & 12.00 & 2.00 & 5.00 & 5.00 & 0.00 & 3.00 & 27.00 \\
\hline Min. & 12 & 2 & 5 & 5 & 0 & 3 & 27 \\
\hline Max. & 12 & 2 & 5 & 5 & 0 & 3 & 27 \\
\hline \multicolumn{8}{|l|}{$1-12$ months } \\
\hline Mean & 12.38 & 2.58 & 6.29 & 5.63 & 1.08 & 1.63 & 29.63 \\
\hline Min. & 10 & 0 & 4 & 2 & 0 & 0 & 23 \\
\hline Max. & 14 & 4 & 10 & 9 & 3 & 4 & 39 \\
\hline S.D. & 1.05 & 1.06 & 1.60 & 1.55 & 0.77 & 1.34 & 3.78 \\
\hline \multicolumn{8}{|l|}{$1-3$ years } \\
\hline Mean & 12.09 & 2.27 & 5.45 & 4.45 & 1.50 & 2.09 & 27.86 \\
\hline Min. & 7 & 0 & 1 & 2 & 0 & 0 & 18 \\
\hline Max. & 14 & 4 & 9 & 7 & 3 & 4 & 37 \\
\hline S.D. & 1.82 & 1.03 & 1.79 & 1.59 & 1.01 & 1.26 & 4.96 \\
\hline \multicolumn{8}{|l|}{$3-6$ years } \\
\hline Mean & 12.63 & 2.42 & 6.47 & 5.32 & 1.21 & 2.47 & 30.53 \\
\hline Min. & 11 & 1 & 3 & 3 & 0 & 0 & 23 \\
\hline Max. & 14 & 4 & 10 & 7 & 3 & 5 & 38 \\
\hline S.D. & 1.11 & 0.90 & 2.06 & 1.45 & 0.91 & 1.64 & 4.11 \\
\hline \multicolumn{8}{|l|}{$6-12$ years } \\
\hline Mean & 12.24 & 2.29 & 5.67 & 4.38 & 1.10 & 2.00 & 27.67 \\
\hline Min. & 10 & 1 & 3 & 1 & 0 & 0 & 20 \\
\hline Max. & 15 & 4 & 8 & 7 & 3 & 4 & 35 \\
\hline S.D. & 1.44 & 0.71 & 1.56 & 1.77 & 0.94 & 1.18 & 4.01 \\
\hline \multicolumn{8}{|l|}{$12-14$ years } \\
\hline Mean & 11.54 & 3.00 & 6.08 & 6.08 & 1.38 & 1.85 & 30.00 \\
\hline Min. & 10 & 2 & 2 & 3 & 0 & 1 & 22 \\
\hline Max. & 14 & 4 & 9 & 8 & 3 & 4 & 38 \\
\hline S.D. & 1.19 & 0.70 & 2.13 & 1.75 & 0.76 & 1.14 & 4.47 \\
\hline
\end{tabular}

\begin{tabular}{|c|c|c|c|c|c|c|c|}
\hline \multirow[t]{2}{*}{ Birth order } & \multicolumn{6}{|c|}{ Coping mechanism } & \multirow{2}{*}{$\begin{array}{l}\text { Total } \\
\text { score }\end{array}$} \\
\hline & $\begin{array}{l}\text { Problem } \\
\text { focused }\end{array}$ & $\begin{array}{l}\text { Seeking social } \\
\text { support }\end{array}$ & $\begin{array}{c}\text { Passive } \\
\text { acceptance }\end{array}$ & Avoidance & Religious & $\begin{array}{l}\text { Emotion } \\
\text { focused }\end{array}$ & \\
\hline \multicolumn{8}{|l|}{ First born } \\
\hline Mean & 12.06 & 2.44 & 5.72 & 4.72 & 1.20 & 1.92 & 28.08 \\
\hline S.D. & 1.50 & 0.83 & 1.95 & 1.65 & 0.85 & 1.39 & 4.08 \\
\hline Min. & 7 & 1 & 1 & 2 & 0 & 0 & 18 \\
\hline Max. & 14 & 4 & 10 & 9 & 3 & 5 & 39 \\
\hline \multicolumn{8}{|c|}{ Consecutive births } \\
\hline Mean & 12.38 & 2.50 & 6.22 & 5.48 & 1.26 & 2.10 & 29.96 \\
\hline S.D. & 1.22 & 1.01 & 1.62 & 1.68 & 0.94 & 1.28 & 4.39 \\
\hline Min. & 10 & 0 & 3 & 1 & 0 & 0 & 20 \\
\hline Max. & 15 & 4 & 10 & 8 & 3 & 5 & 38 \\
\hline
\end{tabular}

Among children with CHD, 24\% were from the age group 1-12 months, $56 \%$ were male, $50 \%$ were first born, $8 \%$ had positive family history of congenital anomalies, and $19 \%$ were post-operative.

Parents of preschool children were found to use more coping mechanism, followed by adolescence group. Parents of preschool children scored highest in problem focused coping and passive acceptance coping. Parents of adolescence scored highest in seeking social support and avoidance coping. Score on religious coping was highest in parents of toddler, and score on emotion-focused coping was highest in parents of neonate. This result is consistent with the study conducted by Gudmundsdottir which reported that the family's coping was different from what it was shortly after the defect was discovered and as the child grows and become adolescence. ${ }^{7}$

Parental coping mechanism was used less when first-born child was diagnosed with CHD rather than the consecutive birth. Coping scores on all six aspects of coping were higher among the parents of children who were consecutive births 


\begin{tabular}{|c|c|c|c|c|c|c|c|}
\hline \multirow{2}{*}{$\begin{array}{l}\text { Sex of } \\
\text { the child }\end{array}$} & \multicolumn{6}{|c|}{ Coping mechanism } & \multirow{2}{*}{$\begin{array}{l}\text { Total } \\
\text { score }\end{array}$} \\
\hline & $\begin{array}{l}\text { Problem } \\
\text { focused }\end{array}$ & $\begin{array}{l}\text { Seeking social } \\
\text { support }\end{array}$ & $\begin{array}{c}\text { Passive } \\
\text { acceptance }\end{array}$ & Avoidance & Religious & $\begin{array}{l}\text { Emotion } \\
\text { focused }\end{array}$ & \\
\hline \multicolumn{8}{|l|}{ Male } \\
\hline Mean & 12.04 & 2.38 & 5.93 & 4.89 & 1.32 & 2.05 & 28.63 \\
\hline S.D. & 1.52 & 1.01 & 1.95 & 1.79 & 0.87 & 1.22 & 4.35 \\
\hline Min. & 7 & 0 & 2 & 2 & 0 & 0 & 18 \\
\hline Max. & 14 & 4 & 10 & 9 & 3 & 5 & 39 \\
\hline \multicolumn{8}{|l|}{ Female } \\
\hline Mean & 12.45 & 2.59 & 6.02 & 5.36 & 1.11 & 1.95 & 29.52 \\
\hline S.D. & 1.13 & 0.78 & 1.62 & 1.55 & 0.92 & 1.47 & 4.28 \\
\hline Min. & 10 & 1 & 1 & 1 & 0 & 0 & 20 \\
\hline Max. & 15 & 4 & 9 & 8 & 3 & 5 & 38 \\
\hline
\end{tabular}

\begin{tabular}{|c|c|c|c|c|c|c|c|}
\hline \multirow{2}{*}{$\begin{array}{l}\text { Sex of the } \\
\text { parent }\end{array}$} & \multicolumn{6}{|c|}{ Coping mechanism } & \multirow{2}{*}{$\begin{array}{l}\text { Total } \\
\text { score }\end{array}$} \\
\hline & $\begin{array}{l}\text { Problem } \\
\text { focused }\end{array}$ & $\begin{array}{l}\text { Seeking social } \\
\text { support }\end{array}$ & $\begin{array}{c}\text { Passive } \\
\text { acceptance }\end{array}$ & Avoidance & Religious & $\begin{array}{l}\text { Emotion } \\
\text { focused }\end{array}$ & \\
\hline \multicolumn{8}{|l|}{ Mother } \\
\hline Mean & 12.18 & 2.48 & 5.83 & 4.93 & 1.30 & 1.77 & 28.52 \\
\hline S.D. & 1.43 & 0.87 & 1.92 & 1.68 & 0.90 & 1.38 & 4.54 \\
\hline Min. & 7 & 0 & 1 & 1 & 0 & 0 & 18 \\
\hline Max. & 14 & 4 & 10 & 9 & 3 & 5 & 39 \\
\hline \multicolumn{8}{|l|}{ Father } \\
\hline Mean & 12.28 & 2.45 & 6.18 & 5.35 & 1.13 & 2.38 & 29.78 \\
\hline S.D. & 1.30 & 1.01 & 1.61 & 1.71 & 0.88 & 1.19 & 3.89 \\
\hline Min. & 10 & 0 & 3 & 2 & 0 & 1 & 23 \\
\hline Max. & 15 & 4 & 9 & 8 & 3 & 5 & 38 \\
\hline
\end{tabular}

\section{Table 7: Parental coping scores in relation to child's operative status $(n=100)$}

\begin{tabular}{|c|c|c|c|c|c|c|c|}
\hline \multirow[t]{2}{*}{ Surgery } & \multicolumn{6}{|c|}{ Coping mechanism } & \multirow{2}{*}{$\begin{array}{l}\text { Total } \\
\text { score }\end{array}$} \\
\hline & $\begin{array}{l}\text { Problem } \\
\text { focused }\end{array}$ & $\begin{array}{l}\text { Seeking social } \\
\text { support }\end{array}$ & $\begin{array}{c}\text { Passive } \\
\text { acceptance }\end{array}$ & Avoidance & Religious & $\begin{array}{l}\text { Emotion } \\
\text { focused }\end{array}$ & \\
\hline Mean & 12.16 & 2.53 & 5.74 & 5.42 & 1.11 & 2.16 & 29.11 \\
\hline S.D. & 1.57 & 0.84 & 2.05 & 1.74 & 0.87 & 1.34 & 5.14 \\
\hline Min. & 7 & 1 & 1 & 2 & 0 & 0 & 18 \\
\hline Max. & 14 & 4 & 9 & 8 & 3 & 4 & 38 \\
\hline \multicolumn{8}{|l|}{ Not done } \\
\hline Mean & 12.23 & 2.46 & 6.02 & 5.02 & 1.26 & 1.98 & 29.00 \\
\hline S.D. & 1.33 & 0.94 & 1.75 & 1.69 & 0.90 & 1.34 & 4.14 \\
\hline Min. & 8 & 0 & 2 & 1 & 0 & 0 & 20 \\
\hline Max. & 15 & 4 & 10 & 9 & 3 & 5 & 39 \\
\hline
\end{tabular}

than the parents of first-born children with CHD. This finding is supported by the study result by Svavarsdottir which showed that parents of later-born infants with a CHD experienced higher levels of family system demands than did first-time parents. ${ }^{8}$

Parents of female children used more coping mechanism than parents of male child. Parents of female children scored highest in problem focused coping, seeking social support coping, passive acceptance coping and avoidance coping, while parents of male children scored highest in religious coping, and emotion focused coping.
Fathers of children with CHD were found to be using more coping mechanisms than the mothers. Fathers scored higher in problem focused coping, passive acceptance coping, avoidance coping, and emotion focused coping; seeking social support coping, and religious coping was used most by mothers. This result is consistent with the findings of Spijkerboer which concluded that mothers appeared to seek social support more often compared to fathers. ${ }^{9}$

Parents of operated children with CHD used more coping mechanisms than parents of non-operated children. Parents 
of postoperative children scored higher in seeking social support coping, avoidance coping, and emotion focused coping. Parents of non-operated children with CHD scored higher in problem focused coping, passive acceptance coping and religious coping. This finding is consistent with the finding of the study by Utens which mentioned that elevated levels of psychological distress, and less adequate styles of coping, were found in the parents of patients about to undergo cardiac surgery, especially the mothers, when compared to reference groups. ${ }^{10}$

\section{CONCLUSION}

Parents of older children, preschool children, female children, operated children, consecutive children, and multiple children used more coping mechanisms. Fathers of children with CHD used more coping mechanisms than mothers. Mothers used seeking social support and religious coping while fathers used problem focused, passive acceptance, avoidance and emotion focused coping. Adequate and appropriate support from the health care providers can enhance parental coping.

\section{ACKNOWLEDGEMENTS}

Our sincere acknowledgment to Associate Professor Mandira Onta, Maharajgunj Nursing Campus for guidance in study and all the participants without whom the study would never have been possible.

\section{REFERENCES}

1. Shah GS, Singh MK, Pandey TR, Kalakheti BK and Bhandari GP. Incidence of congenital heart disease in tertiary care hospital. Kathmandu University Medical Journal 2008; 6(21): 33-36.

2. Majnemer A, Limperopoulos C, Shevell M, Rohlicek C, Rosenblatt $B$ and Tchervenkov $C$. Health and well-being of children with congenital cardiac malformations, and their families, following open-heart surgery. Cardiology in the Young 2006; 16: 157-164.

3. Green A. Outcomes of congenital heart disease. Pediatric Nursing 2004; 30(4)

4. Worret $\mathrm{H}$ and Worret $\mathrm{F}$. Coping mechanisms. Psychiatric Mental Health Nursing. $4^{\text {th }}$ ed. Mosby, 2008; 91-104.

5. Tak YR and Mc Cubbin M. Family stress, perceived social support and coping following the diagnosis of a child's congenital heart disease. Journal of Advanced Nursing 2002; 39(2): 190-198.

6. Bhatti RS, Channabasavnna SM, Prabhu LR, Subbakrishna and Rao S. A manual on family typology scale. National Institute of Mental Health and Neurosciences (NIMHANS), Bangalore, India. 1985.

7. Gudmundsdottir M, Gilliss C, Sparacino P, Tong E, Messias D and Foote D. Congenital heart defects and parent-adolescent coping. Family System \& Health 1996; 14: 245-255.

8. Svavarsdottir EK and McCubbin M. Parenthood transition for parents of an infant diagnosed with a congenital heart condition. Journal of Pediatric Nursing1996; 11(4): 207-216.

9. Spijkerboer AW, Helbing WA, Bogers AJ, Van Domburg RT, Verhulst FC and Utens EM. Long-term psychological distress and styles of coping in parents of children and adolescents who underwent invasive treatment for congenital cardiac disease. Cardiology in the Young 2007; 17(6): 638-45.

10. Utens EM, Versluis-Den Bieman HJ, Verhulst FC, Witsenburg M, Bogers AJ and Hess J. Psychological distress and styles of coping in parents of children awaiting elective cardiac surgery. Cardiology in the Young 2000; 10(3): 239-244.

\section{Authors Contribution:}

SB- Conceptualized study, collected data, literature search, statistically analyzed and interpreted, prepared first draft of manuscript; AS- Critical revision of the manuscript, review of literature and helped in preparing first draft of manuscript.

Source of Support: Nil, Conflict of Interest: None. 